\title{
The Politics of Inclusion and Exclusion
}

\author{
Michael Bernhard and Daniel I. O'Neill
}

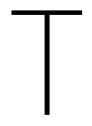
his is the first issue that the University of Florida editorial team has fully managed the journal's production process. The contents are still a combination of materials developed by our team and that of our predecessors at Indiana University. The current issue includes two special features. First, we have the honor of publishing David Lake's APSA Presidential Address from this year's annual meeting. Second, thematically we have several articles that address issues of inclusion and exclusion, both in political life and the political science profession.

\section{The Presidential Address}

The first article in the first number of every volume of Perspectives on Politics is that year's APSA presidential address. As one does not get to be president of the association without having an exemplary academic career, we consider the publication of the address to be a major event which it is our privilege to host. This year's address by David Lake is no exception.

David Lake is the Jerri-Ann and Gary E. Jacobs Professor of Social Sciences and Distinguished Professor of Political Science at the University of California, San Diego and a member of the American Academy of Arts and Sciences. He is a leading thinker in international relations and has written on numerous topics including the state, international political economy, war and conflict, international order, and American foreign policy. This is not his first appearance in the journal. His 2016 piece, "White Man's IR: An Intellectual Confession," drew broad public attention in its appeal for the incorporation of gender, racial, and other forms of diversity into the study of international relations. ${ }^{1}$

Lake's presidential address, "International Legitimacy Lost? Rule and Resistance When America Is First," looks at the future prospects for American foreign policy in the age of Trump. In thinking about the liberal democratic order that the United States established after World War II, Lake readily acknowledges that particular states and regions benefitted from that order (e.g. Western Europe and Northeast Asia), while others had good reason to be unhappy with or resist it (the Middle East, the Caribbean). The Pax Americana was not unilaterally imposed on the globe, but supported by a strong coalition of allied states with shared interests. Lake argues that Trump's populism poses a threat to the continuation of this state of affairs because his "America first" policies have the potential to drive a wedge between the United States and its most important allies in Western Europe and Northeast Asia.

\section{The Politics of Inclusion and Exclusion}

American national politics, as well as the rise of democracy in individual states, can be read as a series of struggles by formerly excluded and stigmatized groups for the same rights as other citizens. In the United States we can see this in the struggles of various waves of immigrants, in the historical and on-going civil rights battles of African Americans and Latinos, in the women's movement, and more recent in civil rights struggles over LGBTQ issues. The rise of democracy in many parts of the world is also cast as a contest by new social forces, like that of the middle and working classes, to secure representation and have their votes count. ${ }^{2}$ In some regions, the fight to compel the state to treat citizens of different ethnic backgrounds equally also represents a formidable challenge. ${ }^{3}$ And gender studies reminds us that democracy is not complete until women and LGBTQ populations are fully empowered as well. ${ }^{4}$ The articles in this section discuss fights for inclusion in a variety of settings and provide a range of new insights into them.

The first piece, "The Importance of Public Meaning for Political Persuasion," contributes to the growing literature on the politics of sexuality. Deva Woodly explores the extent to which changes in the attitudes of the American population on same-sex relationships underlie the successful struggle for same-sex marriage. Despite the fact that a majority of Americans found same-sex relationships to be wrong "some of the time," a majority of Americans have also come to approve of same-sex marriage. Woodly explains this by showing how activists were able to change the criteria by which Americans judged same-sex marriage and moved the debate away from sexual relationships to issues of marriage, family, and equality.

In "Schooling as a Formative Political Experience: Authority Relations and the Education of Citizens," Sarah Bruch and Joe Soss examine how education affects the 
ways in which citizens participate in politics. They show that negative school-authority experience depresses participation in politics and trust in government by young citizens. They demonstrate how race, class, and gender, as well as their intersection, become the bases of social hierarchy and help to produce and maintain inequalities in citizenship. They argue that education thus unwittingly becomes a means of maintaining rather than overcoming inequality among citizens.

George Thomas also takes up the issue of same-sex marriage in "Religious Liberty, Same-Sex Marriage, and Public Accommodations." He considers the contentious claim that religious conviction ought to trump the rights of same-sex couples to equal treatment under the law. Thomas explores this issue in the commercial sphere where culturally conservative activists have tried to create accommodations to allow them to continue to discriminate in transactions that involve same-sex marriage partners. He argues that such exemptions are a form of legal overreach, because equal access in the commercial sphere does not imply moral approval but only demands the toleration of difference.

The next piece, "Coalitions and the Diffusion of Gender Quotas: Theory and Evidence from Africa," by Alice Kang and Aili Tripp, takes us halfway around the globe to examine institutional innovation in the representation of women. Kang and Tripp investigate the role of women's movements in the adoption of quotas to assure minimal levels of female representation in parliaments in Africa, where such provisions are relatively common. They highlight the role of interethnic coalitions in quota adoption success, highlighting this both in a large-n study of Africa and illustrative case studies of quota adoption in Senegal and non-adoption in Benin.

The final piece in this special section is by Daniel Levine and David McCourt, who turn a critical eye to the subfield of international relations in "Why Does Pluralism Matter When We Study Politics? A View from Contemporary International Relations." The authors argue against a form of pluralism in which competing paradigms recognize, but also clash with, each other within the subfield. They label this acknowledgment of the increased diversity of approaches to the study of international relations "plurality," and go on to argue that true "pluralism" goes well beyond registering the multiplicity of approaches within the field to an acceptance that there is no singular path to truth about international relations.

\section{Other Content}

This issue includes one other article, "When Is It Rational to Learn the Wrong Lessons? Technocratic Authority, Social Learning, and Euro Fragility," by Mathias Matthijs and Mark Blyth. In a major statement on the current crisis of the Euro and the slowness of the European economic recovery following the great recession, the authors show that European elites pursued a set of policies that were economically irrational but politically rational. They show that the loose monetary policy of the European Central Bank, while in direct opposition to the tight fiscal policy imposed by the member states' governments, contributed to the resilience of the Eurozone as a political entity. This contradictory combination of policies helps to explain how Europe's anti-recessionary policies led to poor macroeconomic results, yet nevertheless allowed Europe to muddle politically through the crisis.

The issue also includes the first two "Reflections" pieces that our team developed for the journal. This longstanding feature of Perspectives allows authors to address significant issues confronting the discipline in a more essayistic format. Here, Frank-Borge Wietzke and Andy Sumner take up the question of "The Developing World's New Middle Classes." While income inequality has tended to grow within most countries in the world, global inequality has been on the decline because of extensive economic growth in the developing world. This growth has led to the creation of new, large middle-class populations. Wietzke and Sumner explore the ramifications of this change for politics and political economy. They note that in lower-middle-income countries this new middle class will be less prosperous than in more developed areas of the globe and, for this reason, it may not have the same sanguine effects that middle-class expansion has had in other areas and periods, such as pressure and support for democracy and more inclusive social policies. Wietzke and Sumner argue that these developments could also lead to new distributional conflicts between the new middle classes and more established and prosperous middle-class groups.

Finally, Kristen Renwick Monroe writes a cautionary essay on the DA-RT (Data Access and Research Transparency) initiative-"The Rush to Transparency: DA-RT and the Potential Dangers for Qualitative Research." She stresses her commitment to both principles (access and transparency) but argues that the rush to adopt an abstract commitment to these values was insensitive to the needs of qualitative researchers and potentially puts qualitative research at a disadvantage for a range of logistical, ethical, economic, and intellectual reasons. She argues that instead of a rush to compliance, careful consideration is necessary because of differences between the needs of researchers who use qualitative and quantitative data and methods.

\section{Changes in the Editorial Board}

Whereas changes in the editorial board under our tenure were announced on the last masthead, our introductory essay had a deadline that prevented us from discussing the changes. Several long-serving members retired from the board with deep thanks for their long and productive service to the journal. The group rotating off the board 
was Dara Strolovitch, Stathis Kalyvas, Melissa Nobles, James Scott, Lisa Wedeen, Marc Morjé Howard, Daniel Drezner, Page Fortna, Edwina Barvosa, Timothy Kaufman-Osborn, Elizabeth Markovits, and Richard Battistoni. They will all be missed for their wise counsel and outstanding contributions to the journal.

We asked several others to join us and we were lucky to get an equally talented, committed, and visible group of scholars to help shoulder the responsibility of running the journal: Reşat Bayer, Nancy Bermeo, Simone Chambers, Katherine Cramer, Anna Grzymala-Busse, Michael Hanchard, Daniel Kapust, Douglas Lemke, Julia Lynch, Joergen Moeller, Ed Schatz, Joan Tronto, and Ashutosh Varshney. Please join Dan, Jen, and I in welcoming them. These additions also mark our first efforts to internationalize the board. We have invited several members who are not based in the United States, including scholars from Canada, Denmark, England, and Turkey. Of course, historically Perspectives has included many board members who were not born in the United States, or who have spent parts of their careers overseas, but this was an explicit effort to bring non-U.S.-based scholars onto the editorial board.

\section{Data Access and Research Transparency}

In light of Kristen Renwick Monroe's "Reflections" piece for this issue, it is worth noting that Perspectives on Politics did not sign onto the original DA-RT statement under Jeff Isaac's editorship. We agree with that decision. We certainly support widely accessible public data and research transparency, but do not see these as absolute values. We believe that there can be tradeoffs between these values and others that we hold dear, and seek to balance these competing commitments. As such, we consider ourselves kindred spirits with those journal editors who have been cautious to adopt a one-size fits all model, such as the editors of Comparative Political Studies, The European Journal of Political Research and World Politics. We also applaud the caution exercised by the American Political Science Review in this regard. ${ }^{5}$

The journal is thus exploring different ways to promote data access and research transparency. The first of these steps has been to create a Perspectives on Politics dataverse, and beginning with this issue quantitative articles that appear in the journal will also be required to post their data and analysis there. Such requirements are routine and uncontroversial among quantitative scholars. We will take a slower approach with regard to qualitative research. However, we are currently working to update our statement on scholarly recognition and supplementary materials. We are also actively working with qualitative authors to develop new ways to enhance the transparency of data and inference through on-line appendices and other mechanisms. We are open to experimenting with authors who seek to be trail-blazers in this regard.

\section{Calls for Papers}

One innovation that we proposed when we applied for the editorship was the creation of special issues and sections devoted to exploring important and intriguing questions of the day. By the time of the publication of this essay, the first two of these calls should have been issued-one on "The Trump Presidency: Causes and Consequences," and one on "The Politics of Celebrity." These papers will go through the normal peer review process and are open to all scholars. If you have missed the calls they can be found here (www.cambridge.org/core/ journals/perspectives-on-politics/call-for-papers). If you have questions about these initiatives you can write to us at perspectives@apsanet.org.

\section{Notes}

1 Lake 2016. See the Altmetric page for Twitter and blogging activity in response to this article here: https://www.altmetric.com/details/15201136.

2 O’Donnell 1973, Collier and Collier 1991, Collier 1999, Luebbert 1991, Ahmed 2015, and Rueschemeyer, Stephens, and Stephens 1992.

3 Kopstein and Wittenberg 2010, Mickey 2015, Gibson 2013, Boone 2014, and Marx 1998.

4 Paxton 2000, Banaszak 1996.

5 The most recent data reproduction policy statement by the APSR includes the following: "To encourage qualitative scholars to make their research transparent and accessible, we will request authors to archive relevant evidence and research protocols where possible. The editors recognize that reproduction standards in qualitative research are under discussion, and authors who are unsure about the nature of the evidence required can contact the editors for clarification. We also urge authors to consult our 'frequently asked questions' page, which will be updated periodically. Appropriate embargo periods for both quantitative and qualitative research materials will be negotiated with authors where reasons for embargo are consistent with existing guidelines"; http://www.apsanet.org/APSR-Submission-Guidelines, accessed October 30, 2017.

\section{References}

Ahmed, Amel. 2015. Democracy and the Politics of Electoral System Choice. Cambridge: Cambridge University Press. Banaszak, Lee Ann. 1996. Why Movements Succeed or Fail: Opportunity Culture and the Struggle for Woman Suffrage. Princeton, NJ: Princeton University Press.

Boone, Katherine. 2014. Property and Political Order in Africa: Land Rights and the Structure of Politics. Cambridge: Cambridge University Press. 
Collier, Ruth Berins. 1999. Paths toward Democracy: The Working Class and Elites in Western Europe and South America. Cambridge: Cambridge University Press.

Collier, Ruth Berins and David Collier. 1991. Shaping the Political Arena: Critical Junctures, the Labor Movement, and Regime Dynamics in Latin America. Princeton, NJ: Princeton University Press.

Gibson, Edward. 2013. Boundary Control: Subnational Authoritarianism in Federal Democracies. Cambridge: Cambridge University Press.

Kopstein, Jeffrey and Jason Wittenberg. 2010.

"Beyond Dictatorship and Democracy: Rethinking Minority Inclusion and Regime Type in Interwar Eastern Europe," Comparative Political Studies 43(8): 1089-118.

Lake, David. 2016. "White Man's IR: An Intellectual Confession." Perspectives on Politics 14(4): 1112-22.
Luebbert, Gregory. 1991. Liberalism, Fascism, or Social Democracy. Oxford: Oxford University Press.

Marx, Anthony. 1998. Making Race and Nation: A Comparison of the United States, South Africa, and Brazil. Cambridge: Cambridge University Press.

Mickey, Robert. 2015. Paths out of Dixie. Princeton, NJ: Princeton University Press.

O'Donnell, Guillermo. 1973. Modernization and Bureaucratic-Authoritarianism: Studies in South American Politics. Berkeley: Institute of International Studies, University of California.

Paxton, Pamela. 2000. "Women's Suffrage in the Measurement of Democracy: Problems of Operationalization." Studies in Comparative International Development 35(3): 92-111.

Rueschemeyer, Dietrich, Evelene Huber Stephens, and John Stephens. 1992. Capitalist Development and Democracy. Chicago: University of Chicago Press. 


\section{Statement of Mission and Procedures}

Perspectives on Politics seeks to provide a space for broad and synthetic discussion within the political science profession and between the profession and the broader scholarly and reading publics. Such discussion necessarily draws on and contributes to the scholarship published in the more specialized journals that dominate our discipline. At the same time, Perspectives seeks to promote a complementary form of broad public discussion and synergistic understanding within the profession that isessential toadvancing scholarship and promoting academic community.

Perspectives seeks to nurture a political science public sphere, publicizing important scholarly topics, ideas, and innovations, linking scholarly authors and readers, and promoting broad reflexive discussion among political scientists about the work that we do and why this work matters.

Perspectives publishes work in a number of formats that mirror the ways that political scientists actually write:

Research articles: As a top-tier journal of political science, Perspectives accepts scholarly research article submissions and publishes the very best submissions that make it through our double-blind system of peer review and revision. The only thing that differentiates Perspectives research articles from other peer-reviewed articles at top journals is that we focus our attention only on work that in some way bridges subfield and methodological divides, and tries to address a broad readership of political scientists about matters of consequence. This typically means that the excellent articles we publish have been extensively revised in sustained dialogue with the editor-me-to address not simply questions of scholarship but questions of intellectual breadth and readability.

"Reflections" are more reflexive, provocative, or programmatic essays that address important political science questions in interesting ways but are not necessarily as systematic and focused as research articles. These essays often originate as research article submissions, though sometimes they derive from proposals developed in consultation with the editor in chief. Unlike research articles, these essays are not evaluated according to a strict, doubleblind peer review process. But they are typically vetted informally with editorial board members or other colleagues, and they are always subjected to critical assessment and careful line-editing by the editor and editorial staff.

Scholarly symposia, critical book dialogues, book review essays, and conventional book reviews are developed and commissioned by the editor in chief, based on authorial queries and ideas, editorial board suggestions, and staff conversations.

Everything published in Perspectives is carefully vetted and edited. Given our distinctive mission, we work hard to use our range of formats to organize interesting conversations about important issues and events, and to call attention to certain broad themes beyond our profession's normal subfield categories.

For further details on writing formats and submission guidelines, see our website at http://www.apsanet.org/ perspectives/ 